УДК $316.36: 314.5$

\title{
К.Н. Обухов
}

\section{СЕМЕЙНЫЕ И РЕПРОДУКТИВНЫЕ УСТАНОВКИ МОЛОДЫХ ЛЮДЕЙ В УДМУРТСКОЙ РЕСПУБЛИКЕ (ПО МАТЕРИАЛАМ МОНИТОРИНГА «МОЛОДЕЖЬ УДМУРТИИ» 2019 ГОДА)}

В статье представлено описание основных семейных и репродуктивных установок молодых людей, проживающих на территории Удмуртской Республики. Для анализа используются данные, полученные в результате проведения онлайн-опроса молодых людей в период с 1 апреля по 31 августа 2019 года (n=600), дополненные актуальной статистикой территориального органа Федеральной службы государственной статистики по Удмуртской Республике за 2019 и 2020 годы. На указанных материалах делается вывод о наличии общей ориентации молодых людей на поиск сексуального партнера и создание семьи, о стабилизации возраста сексуального дебюта на уровне 17 лет для мужчин и 18 лет для женщин, о росте общей обеспокоенности состоянием здоровья у молодых людей при достаточно высоком уровне распространения рискованного сексуального поведения. В целом по материалам опроса можно констатировать желание молодых людей заводить в среднем двух детей с незначительным смещением в сторону однодетной модели семьи. Существуют базовые расхождения в семейных и репродуктивных установках среди жителей городов и сельской местности Удмуртии. По данным статистики делается вывод о том, что в настоящее время в Удмуртии сохраняются волновой характер половозрастной структуры населения, а также тенденция к фиксации одновременных высоких показателей по брачности и разводимости, что свидетельствует о неподготовленности молодых людей к вступлению в брак при общем сохранении его ценности.

Ключевые слова: молодежь, семья, здоровье, сексуальное поведение, ЗПППП, контрацепция, брачность, разводимость, рождаемость, Удмуртия.

DOI: $10.35634 / 2587-9030-2021-5-3-311-321$

\section{Правильная ссылка на статью:}

Обухов К.Н. Семейные и репродуктивные установки молодых людей в Удмуртской Республике (по материалам мониторинга «Молодежь Удмуртии» 2019 года) // Вестн. Удм. ун-та. Социология. Политология. Международные отношения. 2021. Т. 5, вып. 3. С. 311-321. https://doi.org/ 10.35634/ 2587-9030-2021-5-3-311-321

\section{Введение}

Волновая структура половозрастного состава населения России в настоящее время является источником дисбаланса в социально-экономической сфере страны [4. С. 50]. Удмуртская Республика представляет собой регион максимально приближенный по структуре населения к среднероссийским показателям. Соответственно, для региона характерна ситуация, связанная с резким падением общего количества молодых людей, а также общим снижением демографических показателей брачности, рождаемости при усугубившейся на фоне пандемии COVID-19 статистики по смертности. Все это приводит к потребности более внимательного изучения сложившихся на данный момент в молодежной среде репродуктивных и семейных установок для более адекватного прогнозирования и планирования социально-экономического развития региона.

Одновременно с этим необходимо отметить, что большим количеством исследователей фиксируется изменение значимости тех или иных ценностей и установок в молодежной среде [11. С. 18]. Многочисленные исследования показывают более высокий уровень значения потребления в молодежной среде [2. С. 76], значимость символического статуса [6. С. 339], распространенность неустойчивой занятости [9. С. 403], специфичность сформированных трудовых мотивов [1. С. 326], большую обеспокоенность состоянием своего здоровья [5. С. 170]. Важными элементами подобных смещений в оценках молодежи своего места в социальной среде становится отношение к семье, своему репродуктивному здоровью и детям.

К настоящему моменту общий алармистский дискурс «краха» или «кризиса» семьи в социологии замещается более продуктивным и прагматичным подходом к изучению происходящих трансформаций во внутрисемейных отношениях под влиянием нарастающих социальных изменений. Исследователями констатируется увеличение разнообразия в оформлении семейно-брачных отношений между людьми с формированием новых сценариев родительства, отцовства, совмещения родительства с трудовой занятостью. При этом на больших массивах данных обнаруживается, что альтернатив- 
ные формы семейного устройства, несмотря на свое разнообразие, не являются доминирующими. Происходящие в России изменения относительно репродуктивных стратегий совпадают с изменениями в большинстве стран и связаны с окончанием второго демографического перехода, который не ведет к «депопуляции» или «вымиранию» [3. С. 171]. В статье рассмотрены варианты реализации вышеуказанных сценариев молодежью на территории Удмуртии.

\section{Методика исследования}

В основе статьи лежат два блока эмпирических материалов. Первый блок включает в себя анализ открытых данных территориального органа Федеральной службы государственной статистики по Удмуртской Республикеи за 2019 и 2020 годы. Второй блок представлен данными, которые собираются на протяжении длительного времени (с 2001 года) в рамках мониторинга «Молодежь Удмуртии». Методика проведения данного мониторинга изменялась несколько раз, последние крупные изменения проводились в 2018 году и были направлены на расширение блока вопросов, связанных с репродуктивным поведением молодежи и ее здоровья. С 2014 года мониторинг проводится в рамках онлайн-опроса молодежи Удмуртии (лиц в возрасте от 14 до 30 лет) через добровольное рекрутирование в социальных сетях (преимущественно vk.com). Общий объем стихийной выборки составляет от 630 до 920 респондентов, по результатам проведения опроса применяется процедура взвешивания данных для приведения выборки к 600 респондентам. Взвешивание обеспечивает совпадение структуры генеральной и выборочной совокупности с половозрастной и территориальной структурой молодежи Удмуртии (квотируются пол, возраст, тип поселения). Таким образом, можно оценить доверительный интервал исследования на уровне 4 при доверительной вероятности в $95 \%$. Данные, приведенные в статье, были собраны с 1 апреля по 31 августа 2019 года, для сопоставления используются данные опросов предыдущих лет, которые обычно проводились в ноябре-декабре соответствующего года при аналогичной структуре выборки.

\section{Демографическая ситуация в Удмуртской Республике}

Как было отмечено выше, для Удмуртской Республики характерна волновая половозрастная структура населения (здесь и далее всю статистику по Удмуртии см. в [13]). Подобный эффект возникает вследствие особенностей исторического развития, связанных с советским периодом развития страны [12. С. 58], до сих пор «вклад» в общие потери населения различных исторических событий остается дискуссионным (Гражданская война, ленинские репрессии, голод 20-х гг. ХХ в., сталинские чистки, голод 30-х гг. ХХ в., ВОВ, послевоенный голод и террор), но в любых дискуссиях доминирующим фактором являются потери в годы ВОВ. Для различных регионов вклад вышеуказанных событий может быть менее или более значимым, к сожалению, у нас нет в настоящий момент четких оценок относительно Удмуртской Республики. Но вне зависимости от доминирующих причин цикличность в изменении численности населения по возрастам, а также изменения в количестве браков, разводов и рождении детей создают соответствующую неравномерную нагрузку на всю социальную сферу Удмуртии, провоцируют напряженность на рынке труда. Ситуация усугубляется достаточно высокими показателями миграции, особенно в молодежной среде [8. С. 132]. Как можно видеть на рис. 1, в Удмуртии наблюдается общее снижение численности молодежи (в возрасте от 14 до 30 лет) при формировании пика численности детей в возрасте от 3 до 12 лет. Необходимо отметить, что с течением времени наблюдается общее «сглаживание» волнового характера структуры населения, каждая последующая волна более протяженная, менее высокая; соответственно, мы наблюдаем нормализацию демографической ситуации. Сегодня нет возможности четко сформулировать причины подобного сглаживания, выделить эффекты, связанные с демографической политикой государства, но, по мнению ряда исследователей, эти эффекты достаточно ограниченны, а в некоторых случаях могут приводить к замедлению процесса сглаживания очередной сформировавшейся волны [10. С. 101].

В 2010-х гг. в репродуктивный возраст вступило самое малочисленное поколение, следовательно, в ближайшем будущем будет наблюдаться сокращение числа браков и рождений на территории Удмуртской Республики (рис. 2). Одновременно с этим фиксируется рост показателей, связанных со смертностью (в пенсионный возраст входит многочисленное поколение 50-х - 60-х гг. ХХ в.), процесс роста дополнительно ускоряется из-за пандемии COVID-19 в 2020 году. Таким образом, с 2017 г. в Удмуртии наблюдается естественная убыль населения с ускорением темпов к 2020 г. (рис. 3). 
Семейные и репродуктивные установки молодых людей в Удмуртской Республике...

313 СОЦИОЛОГИЯ. ПОЛИТОЛОГИЯ. МЕЖДУНАРОДНЫЕ ОТНОШЕНИЯ

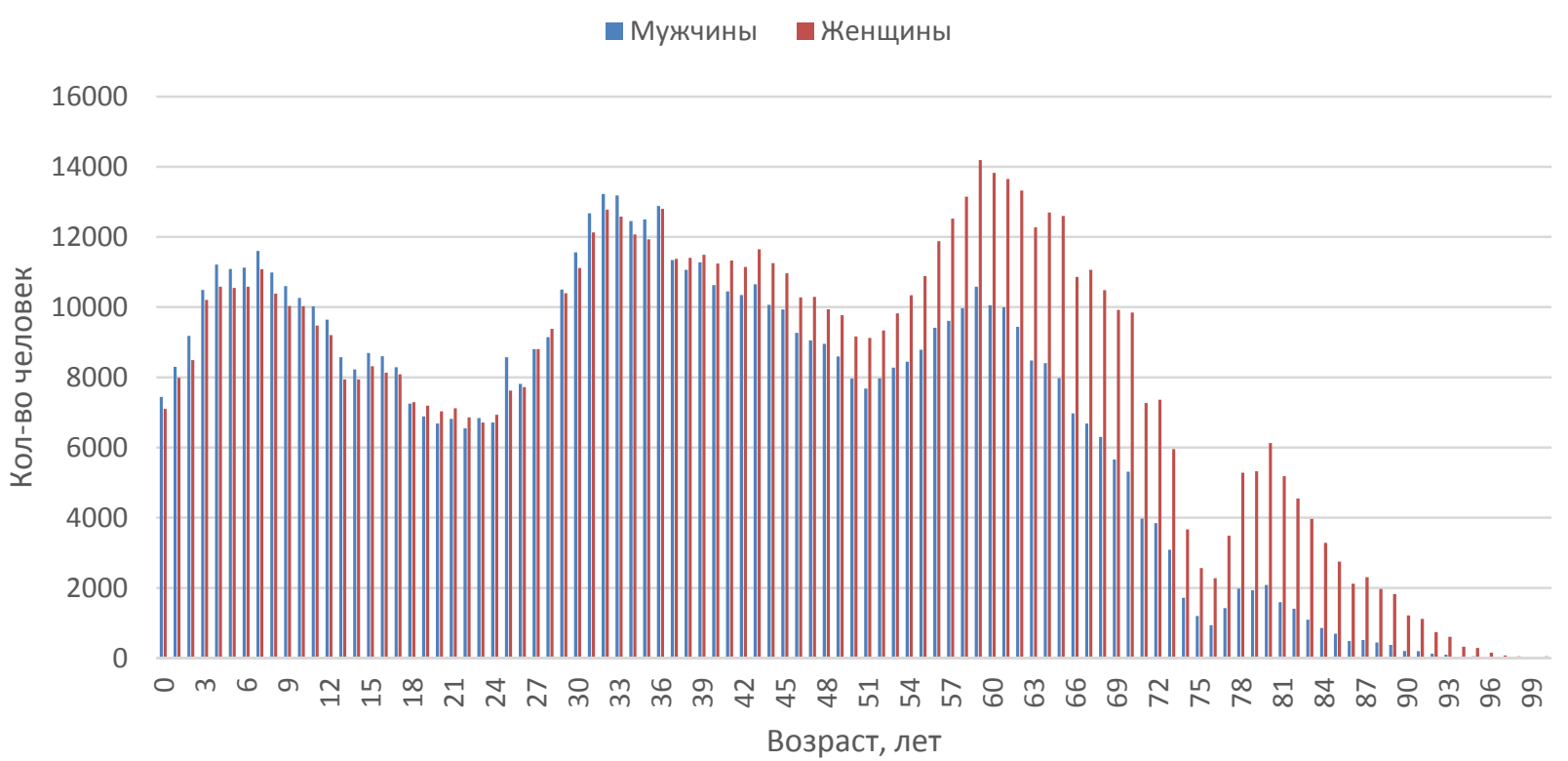

Рис. 1. Половозрастная структура населения Удмуртской Республики на 1 января 2020 года (по данным Удмуртстата)

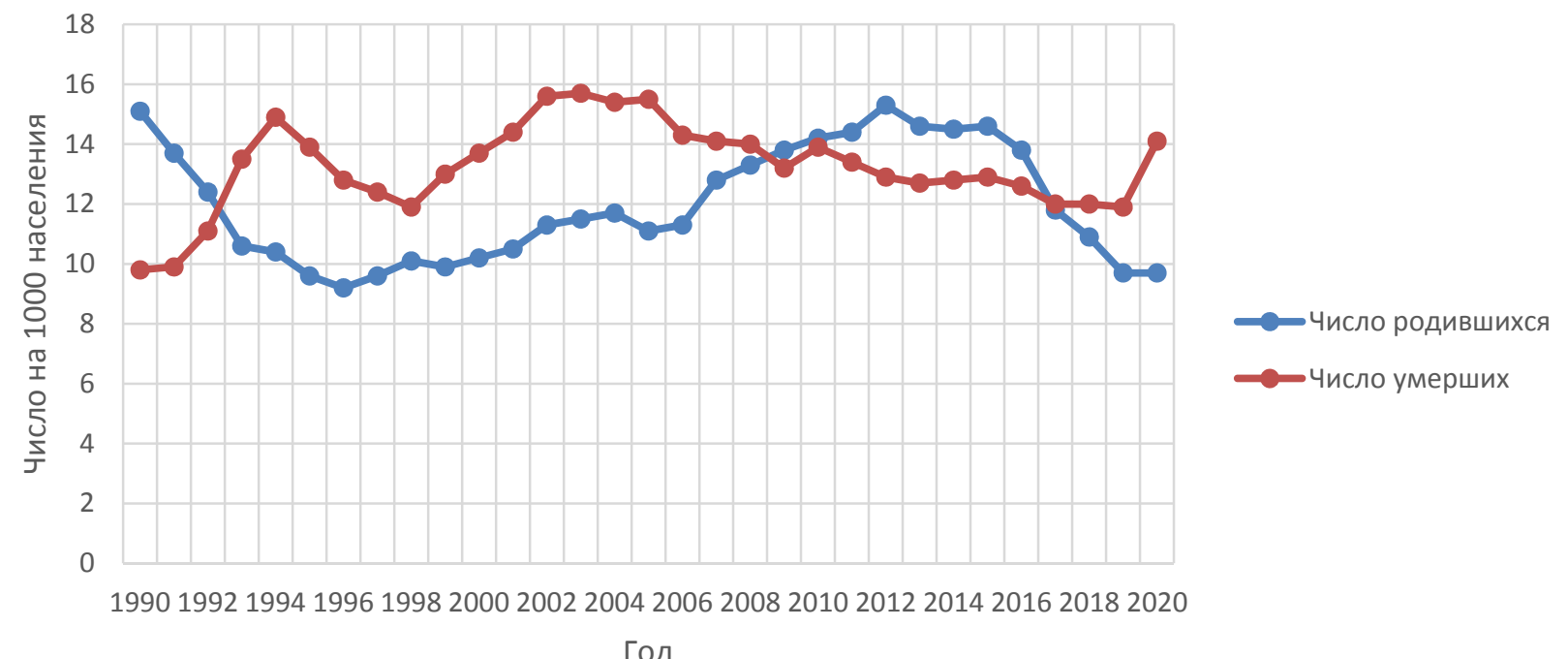

Рис. 2. Число родившихся и умерших по годам на 1000 чел. населения в Удмуртской Республике (по данным Удмуртстата)

Количество новорожденных снижается вслед за падением числа браков (см. рис. 4). Необходимо отметить, что в Удмуртии наблюдается четкая корреляция между этими двумя показателями (при скорректированном количестве рождений на один год) - кор. Пирсона $=0,86$. Кроме того, можно отметить, что для большого количества пар характерно появление детей в течение года после заключения брака.

Ситуация с количеством браков и рождений не полностью зависит от молодого поколения, а определяется более сложными репродуктивными установками возрастных поколений. Многочисленное поколение 80-х гг. XX века, несмотря на то что оно вышло из определения молодежи, продолжает оказывать значительное влияние на демографическую ситуацию в Удмуртии. Особенно наглядно это можно видеть в базовой структуре рождений и браков по возрастам: по годам наблюдается рост вторых и третьих рождений с четким смещением возраста рождения ребенка матерью в сторону 30-40 лет (см. рис. 5, 6). 


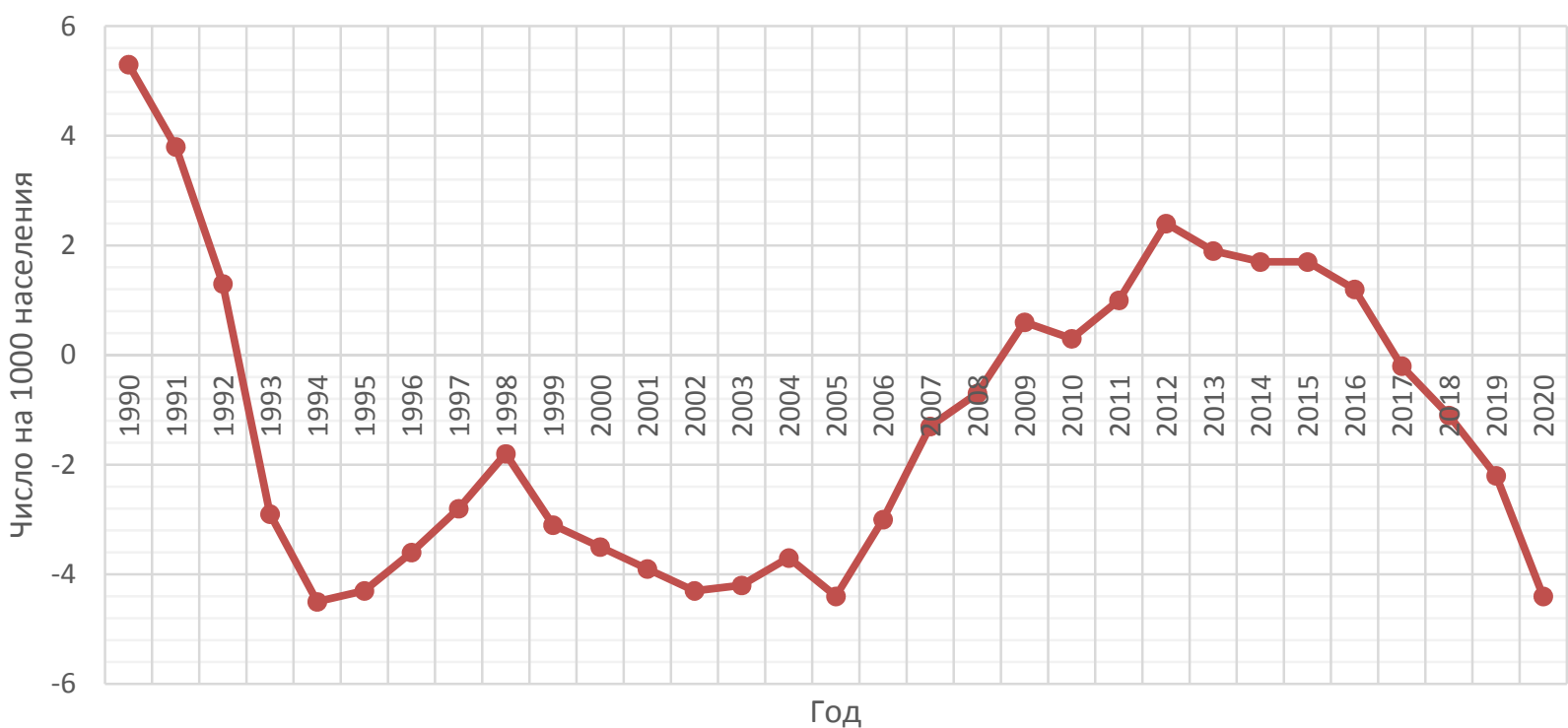

Рис. 3. Естественный прирост (убыль) населения Удмуртской Республики, показатель на 1000 человек (по данным Удмуртстата)

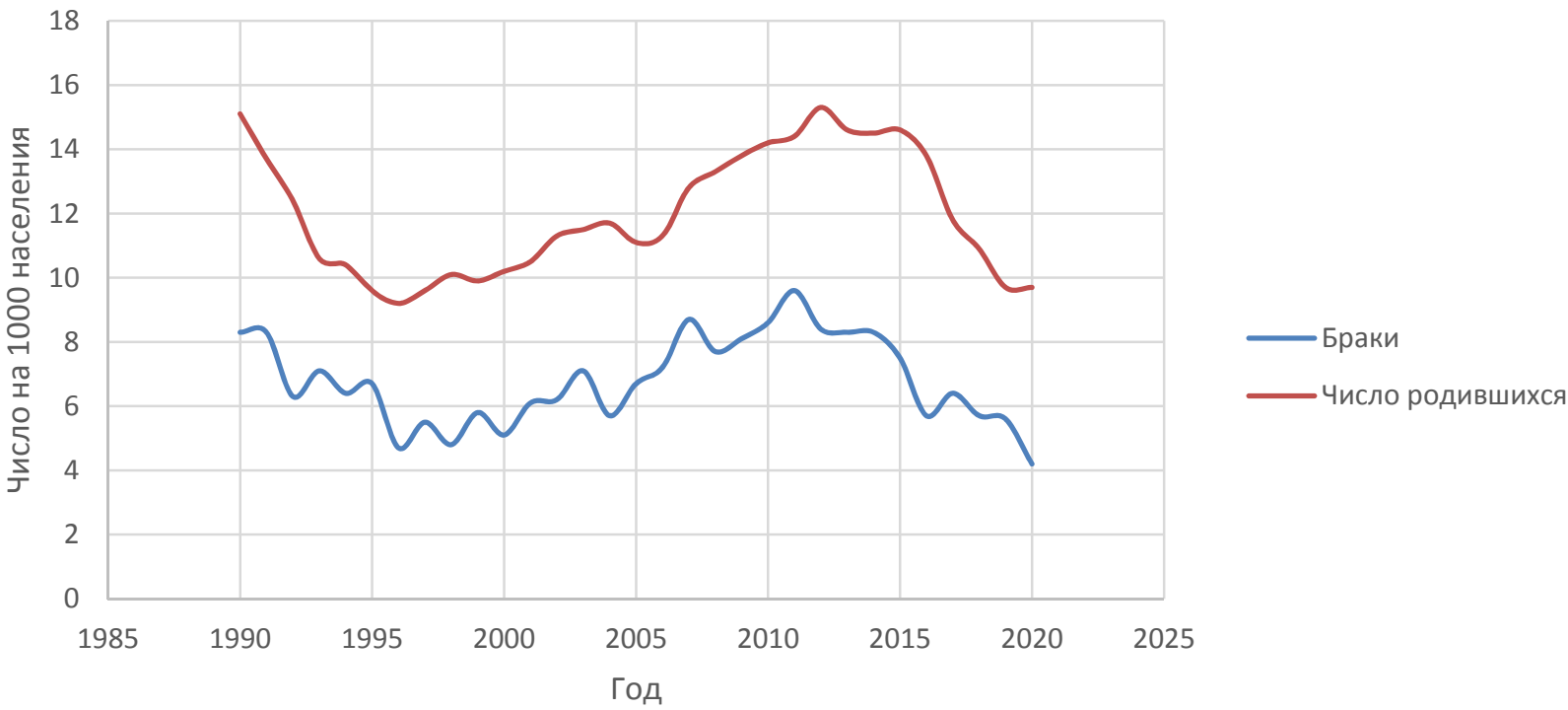

Рис. 4. Динамика количества браков и рождений по годам на 1000 населения в Удмуртской Республике (по данным Удмуртстата)

Одновременно с этим монотонно возрастает и возраст вступления в брак среди молодых людей. Так, показатели средневзвешенного возраста вступления в брак для женщин (без учета порядка брака) в настоящее время находятся на высоком уровне в сравнении с предыдущими десятилетиями 23,66 лет, для мужчин аналогичный показатель - 26,44 года (см. рис. 7, 8).

Ситуация роста синтетического показателя среднего возраста вступления в брак для мужчин и женщин может быть частично связана с общими высокими показателями брачности и разводимости, что и для Удмуртии, и для России в целом становится стандартной ситуацией (см. рис. 9). Это косвенно свидетельствует о неготовности молодых людей к семейной жизни при первичном вступлении в брак одновременно с общей ориентацией молодежи на следование законным способам установления семейных отношений. Соответственно, высокие показатели неподготовленных или ранних браков «поддерживают» относительно стабильные и высокие показатели разводов. 


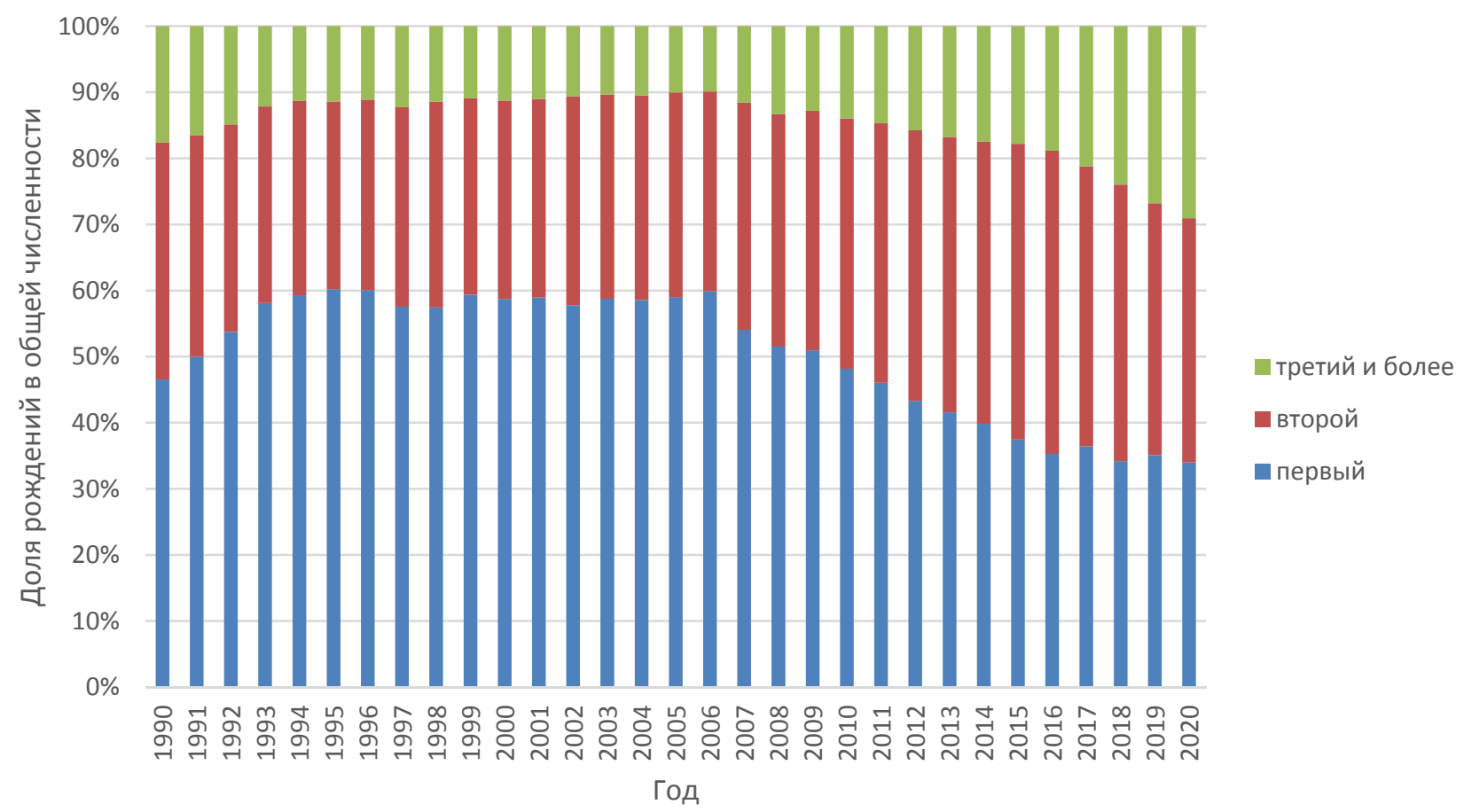

Рис. 5. Доля рождений по количеству детей у одной матери по годам на территории Удмуртской Республики (по данным Удмуртстата)

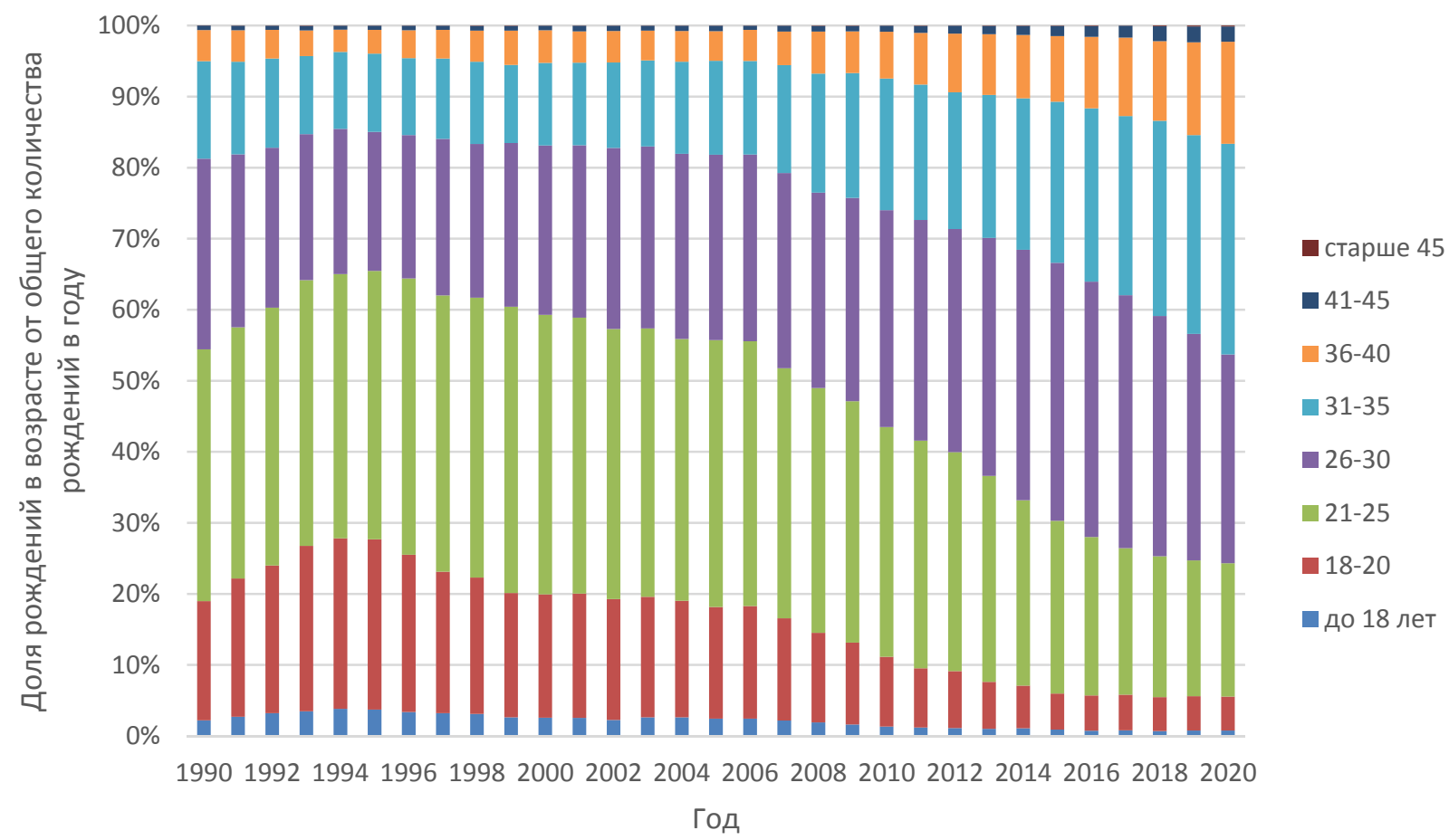

Рис. 6. Доля рождений по возрасту матери от общего количества родов за определенный год на территории Удмуртской Республики (по данным Удмуртстата) 


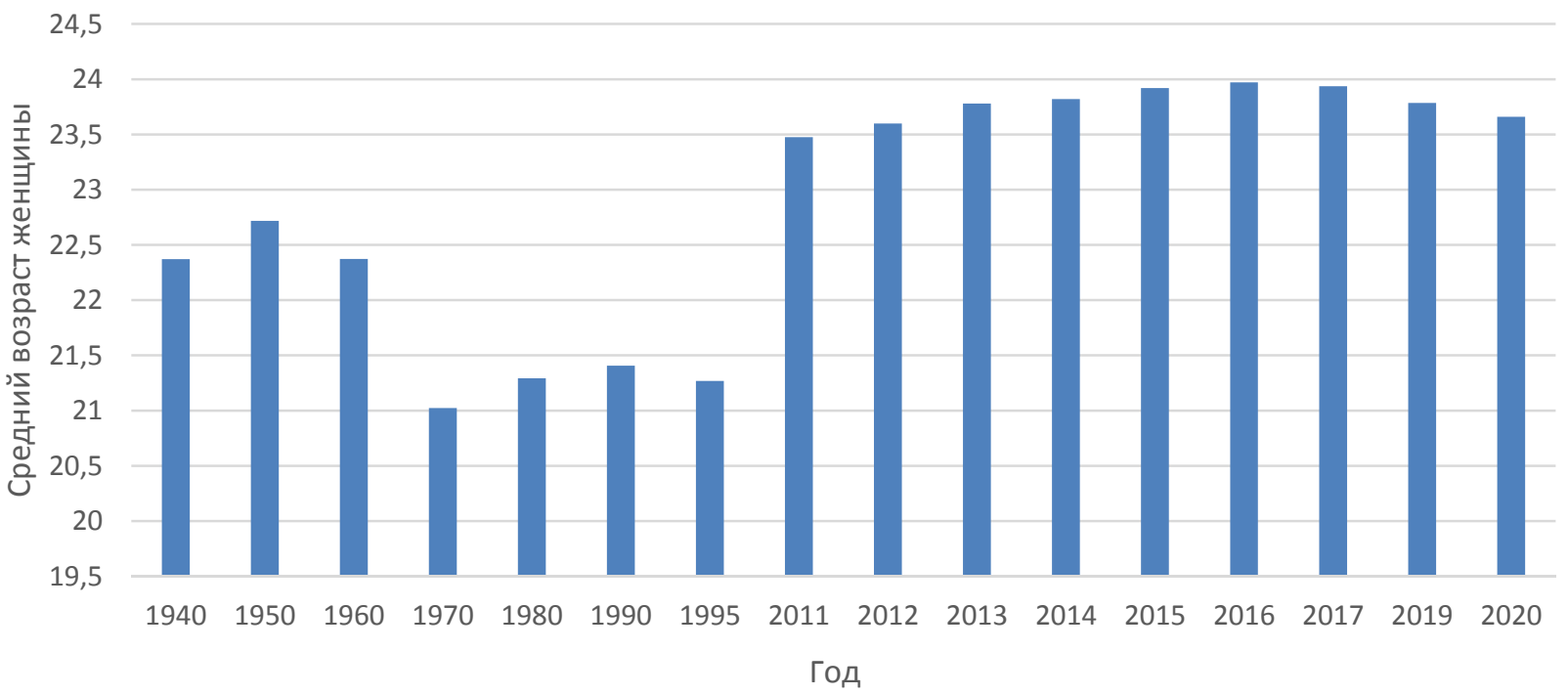

Рис. 7. Средний (взвешенный) возраст вступления в брак (без учета порядка брака) для женщин в возрасте до 30 лет (синтетический расчетный показатель по данным Удмуртстата)

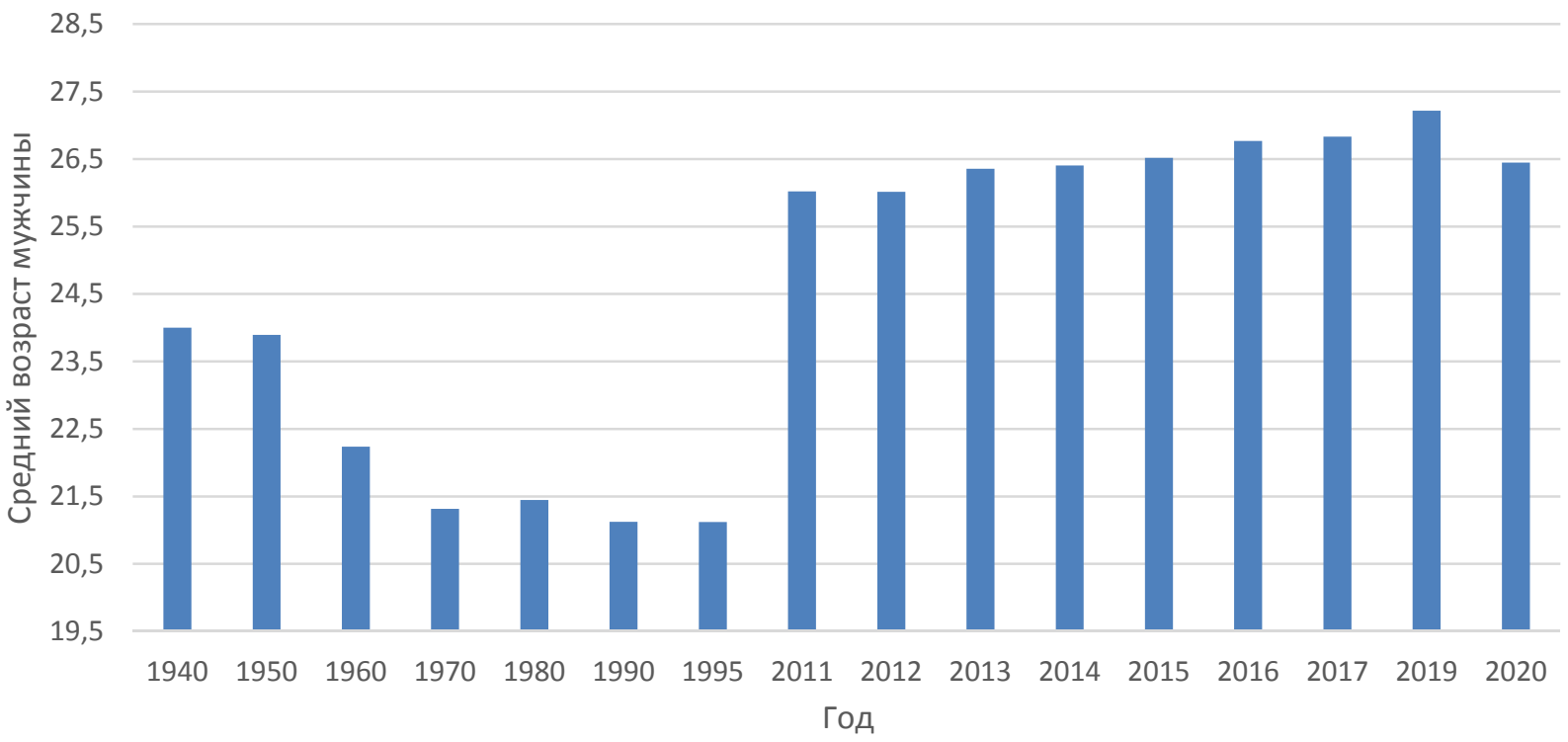

Рис. 8. Средний (взвешенный) возраст вступления в брак (без учета порядка брака) для мужчины в возрасте до 30 лет (синтетический расчетный показатель по данным Удмуртстата)

В целом версию о неподготовленности молодых людей к браку подкрепляет базовая статистика продолжительности расторгнутых браков (см. рис. 10). В целом немногим менее 40 \% разводов происходят после не более чем 4 лет совместной жизни супругов, еще около $1 / 4$ разводов происходит на горизонте 5-9 лет совместного брака.

Анализ официальных статистических данных позволяет зафиксировать продолжение второго демографического перехода на территории Удмуртской Республики, который тесным образом связан с общим волновым характером половозрастной структуры населения. В настоящее время общая ориентация молодых людей на более позднее заключение брака и рождение первого ребенка совпадает с малочисленностью молодого поколения. Ситуация окончания второго демографического перехода сглаживается многочисленным поколением людей, рожденных в 80-е гг. XX века, которые склонны заключать новые брачные союзы после опыта развода и в большей степени ориентированы на трехдетную модель семьи. Представленные статистические данные позволяют лишь косвенно оценивать сложившиеся тенденции, но не формализуют сложившиеся семейно-брачные установки в молодежной среде. Для этого необходимо обратиться к данным социологического опроса среди молодежи. 


СОЦИОЛОГИЯ. ПОЛИТОЛОГИЯ. МЕЖДУНАРОДНЫЕ ОТНОШЕНИЯ

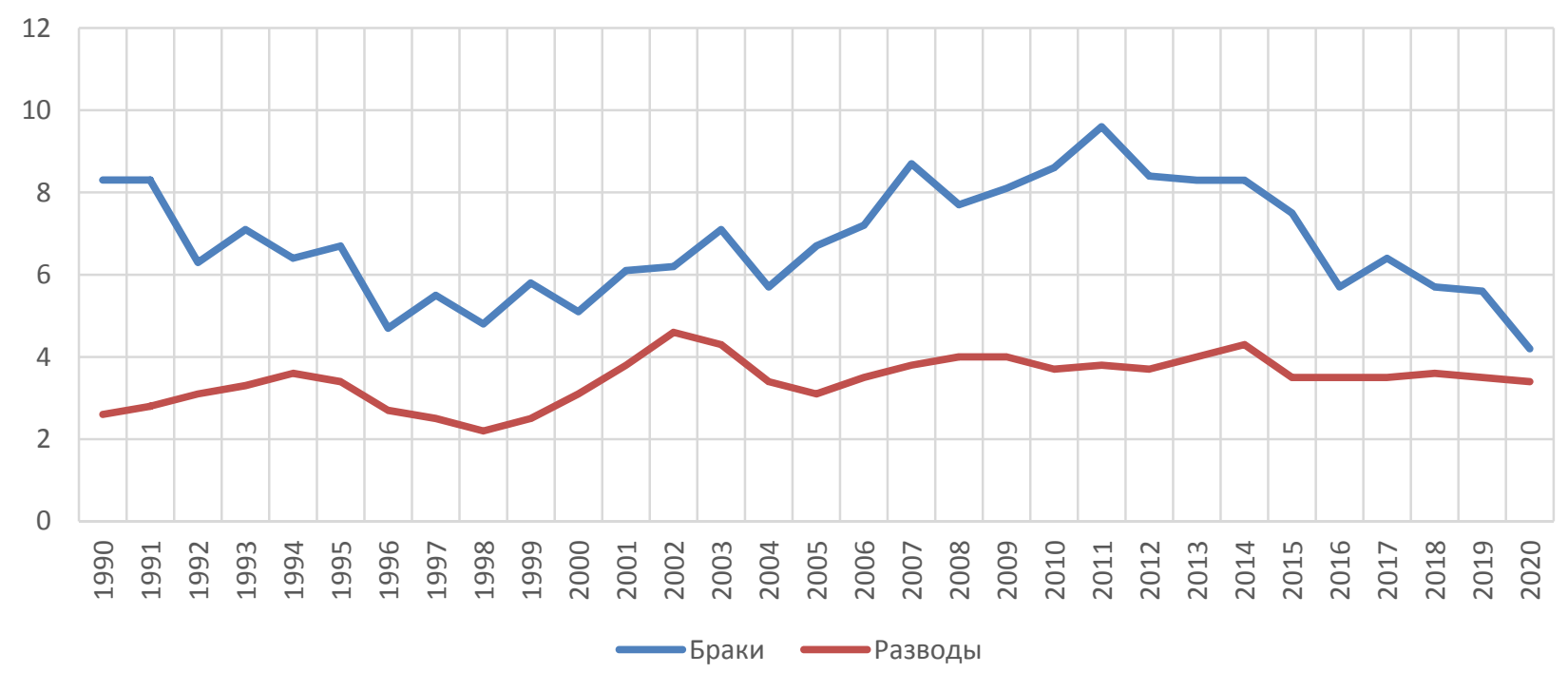

Рис. 9. Браки и разводы на 1000 населения Удмуртской Республики по годам (по данным Удмуртстата)

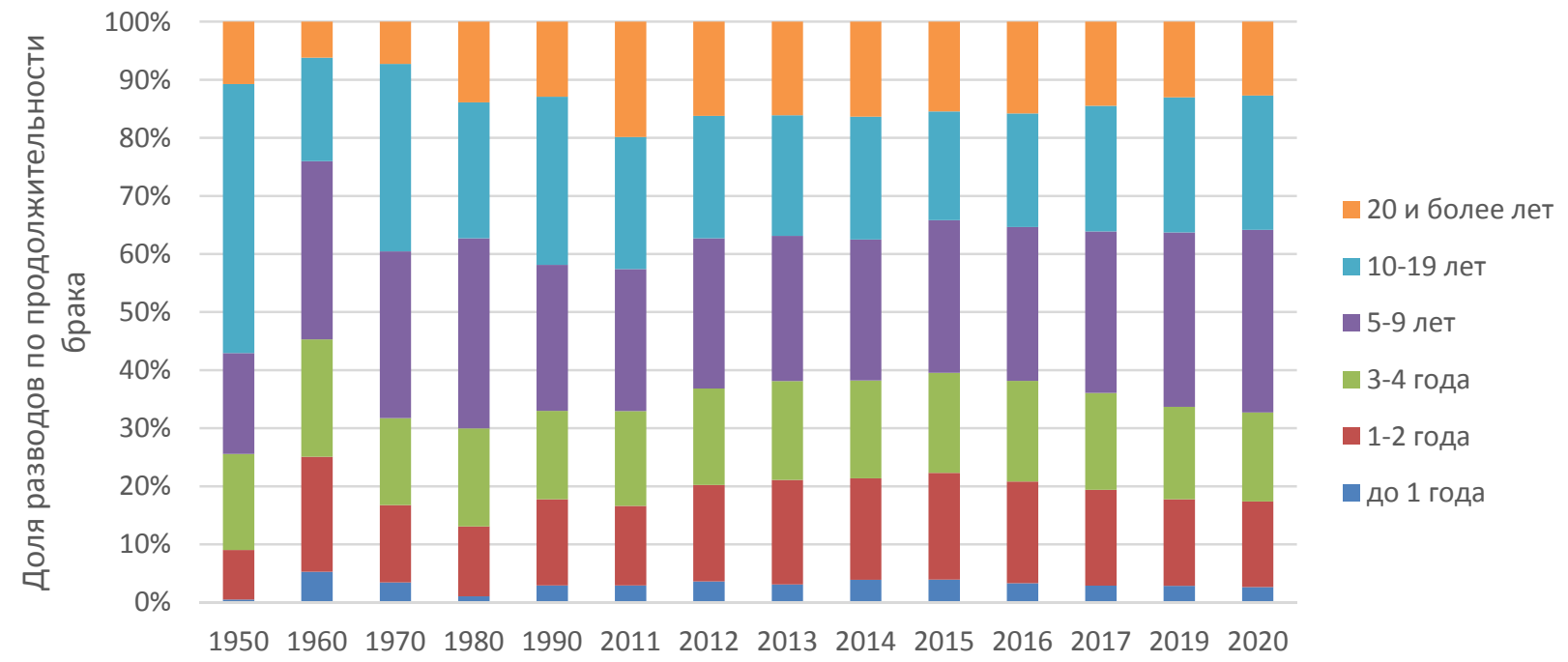

Год

Рис. 10. Доля разводов по продолжительности брака на территории Удмуртской Республики (по данным Удмуртстата)

\section{Сексуальные отношения и брачные установки молодежи Удмуртии}

В целом, по данным мониторинга 2019 года, молодые люди сохраняют ориентацию на романтические отношения. $66 \%$ опрошенных заявили, что у них в настоящее время есть любимый человек, около $1 / 3$ ответили, что они в настоящий момент не влюблены. Традиционно девушки немного чаще юношей сообщают о том, что у них есть любимый человек (69 \% против 61 \%). С увеличением возраста доля тех, кто сообщает о наличии любимого человека, растет. В малых городах Удмуртии (Воткинск, Глазов, Можга, Сарапул) на 10 \% чаще сообщают о том, что в настоящий момент не влюблены. Приблизительно аналогичные показатели характерны и для факта наличия сексуального опыта у молодых людей: 66 \% сообщают о факте наличия у них сексуального опыта, еще $34 \%$ - о его отсутствии. Показатель четко коррелирует с возрастом: чем старше молодой человек, тем выше вероятность встретить у него положительный вариант ответа на этот вопрос.

Традиционно в исследовании задается вопрос о том, в каком возрасте респондентом был получен первый сексуальный опыт. На этом основании на протяжении длительного времени рассчитывается 
показатель среднего возраста сексуального дебюта. С 2014 года наблюдалась ситуация «роста» возраста сексуального дебюта среди молодых людей, но с 2017 года ситуация относительно стабилизировалась с незначительным возвращением к младшим возрастам. Традиционно показатели сексуального дебюта для мужчин и женщин различаются (в среднем на один год).

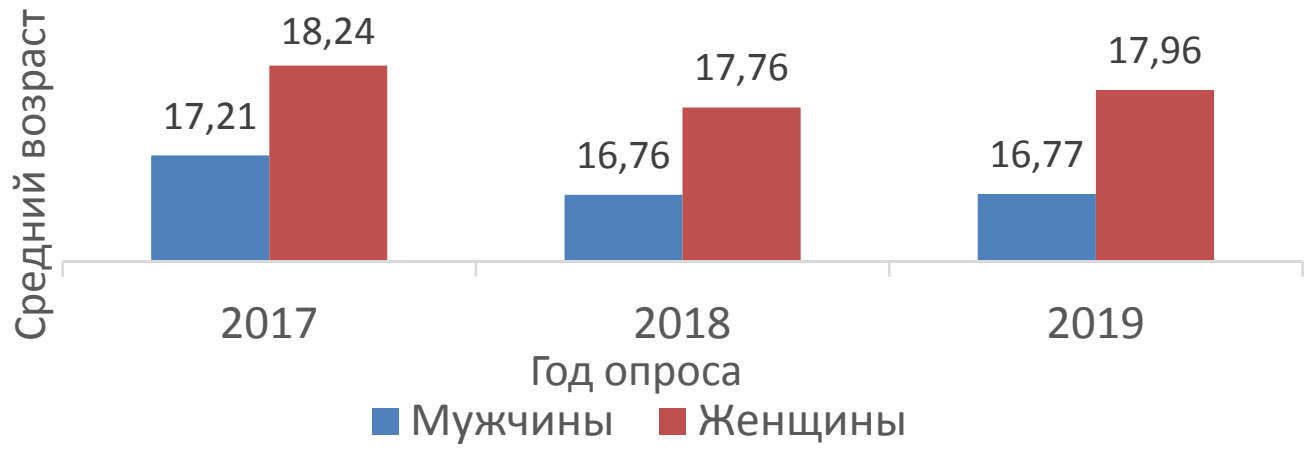

Рис. 11. Показатели среднего возраста сексуального дебюта среди мужчин и женщин по годам (данные мониторинга «Молодежь Удмуртии»)

В целом среди тех, кто имеет сексуальный опыт, подавляющее большинство молодых людей сообщает о наличии у них одного постоянного сексуального партнера $(70,6 \%$ от тех, кто сообщил о наличии сексуального опыта), 11,4 \% сообщают о том, что у них исключительно ситуативные и временные сексуальные связи с разными людьми, 3,5 \% сообщили о том, что у них есть постоянный и временные сексуальные партнеры одновременно, 14,6 \% отметили, что у них есть сексуальный опыт, но в настоящее время не имеют сексуальных связей. Как и в случае с влюбленностью, девушки чаще сообщают о наличии у них постоянного сексуального партнера (79,5 \% против 58,5 \%). Доля ответов об отсутствии сексуального партнера уменьшается с увеличением возраста респондентов. Уровень наличия постоянного сексуального партнера в селе на 10 \% выше аналогичного показателя в Ижевске и малых городах Удмуртии.

Более половины опрошенных респондентов (56 \%) заявляют, что для них брак является обязательной формой регистрации семейных отношений, для $24 \%$ - нет, еще $20,1 \%$ затруднились с ответом на этот вопрос. Для женщин доля утвердительных ответов выше, чем для мужчин $(63,6$ \% против 44,7 \%). Наибольшая доля согласных с тем, что брак необходимо регистрировать в ситуации продолжительных отношений, находится в возрастных когортах 23-30 лет. В сравнении с данными 2018 года наблюдается рост доли респондентов (на 6 \%), которые утвердительно отвечают на вопрос об обязательности регистрации отношений.

Молодым людям в ходе опроса предлагалось назвать идеальный, по их мнению, возраст вступления в брак для мужчин и женщин. На основе ответа на этот вопрос был вычислен средний желаемый возраст вступления в брак, который может быть сопоставлен с фактическим средним возрастом вступления в первый брак для молодых людей до 30 лет по данным Удмуртстата. Традиционно эти показатели находятся на разных уровнях, что косвенно свидетельствует о высоком уровне распространения ранних браков. Так, для мужчин средний желаемый возраст вступления в брак 26,95 лет, при реальном возрасте вступления в первый брак 24,98. Для женщин средний желаемый возраст вступления в брак $-24,23$ лет при реальном возрасте вступления в первый брак $-23,93$. Необходимо отметить, что показатель идеального возраста вступления в брак для молодых людей, которые уже состоят в браке, находится на еще более высоком уровне - 29 лет для женщин, 32 года для мужчин.

\section{Репродуктивные установки и здоровье молодых людей Удмуртии}

В целом подавляющее большинство молодых людей ориентировано на то, чтобы в будущем завести ребенка. Стратегии бездетности не находят широкого распространения среди молодежи. По данным опроса. наблюдается преобладание двухдетной модели семьи с тенденцией незначительного смещения в сторону трехдетной, но при неустойчивости ситуации в опросах по годам (в 2018 году тенденция была смещена в сторону однодетной модели семьи, см. рис. 12). Обращает внимание на себя тот факт, что процент тех, кто планирует рождение детей, во всех возрастных группах схож, де- 
Семейные и репродуктивные установки молодых людей в Удмуртской Республике...

вушки чаще сообщают о желании иметь трех и более детей, чем молодые люди $(20,6$ \% против $15,2 \%)$, двухдетная модель семьи резко доминирует в Ижевске, в то время как трехдетная модель семьи доминирует в сельской местности (28,5 \% от опрошенных, проживающих на селе).

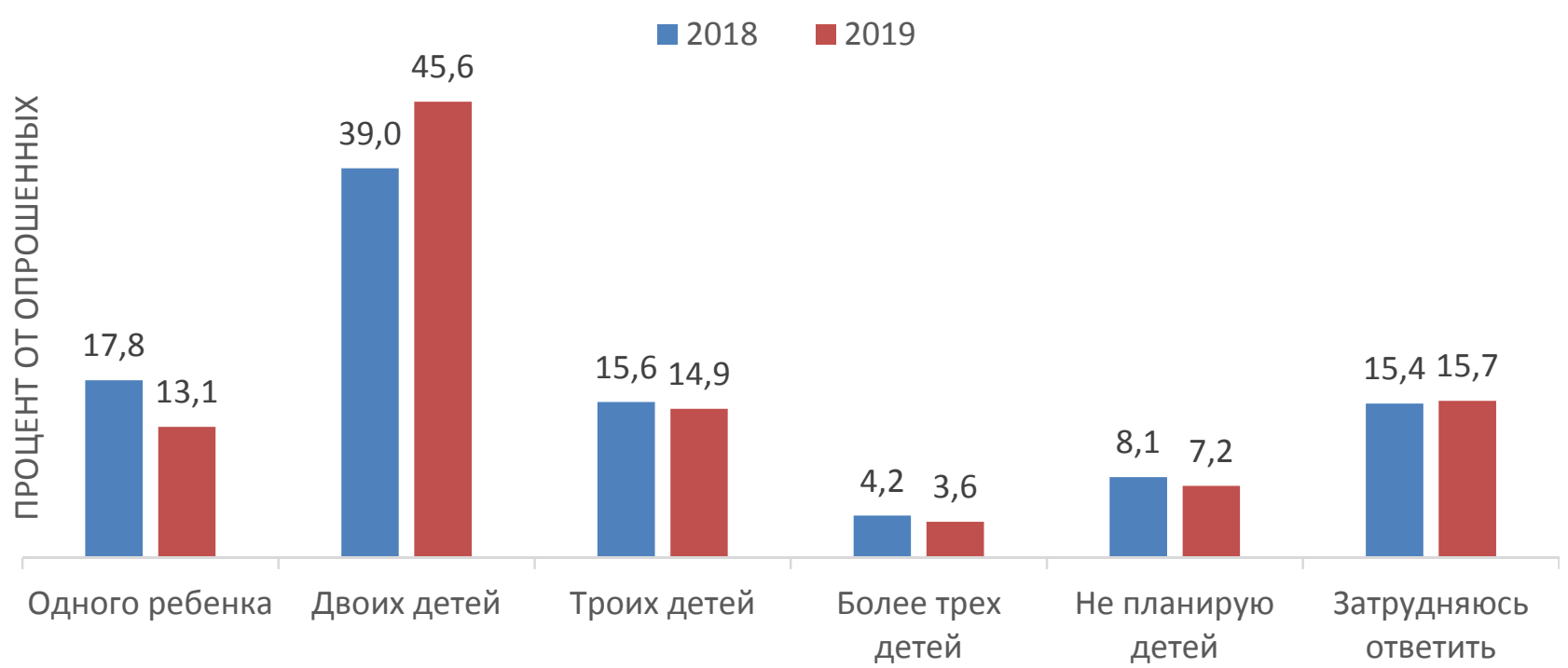

Рис. 12. Планируемое количество детей (данные мониторинга «Молодежь Удмуртии»)

Реализация репродуктивных намерений, особенно с точки зрения молодых людей, может носить различный, в том числе недостаточный, характер. Одним из факторов, которые приводят к снижению фактических рождений относительно желаемых, является состояние здоровья. Общие данные свидетельствуют о том, что ситуация с репродуктивным здоровьем молодых людей может быть подвержена риску ухудшения вследствие распространения рискованного сексуального поведения. Так, по-прежнему остается достаточно высоким процент молодых людей, которые в ситуации сексуального дебюта не использовали презерватив ( $28 \%$ среди тех, кто имеет сексуальный опыт). Необходимо отметить, что средние и старшие возрастные группы намного чаще сообщают, что они не использовали презерватив во время первого сексуального контакта.

Практика регулярного использования презервативов во время секса также не является устоявшейся. Лишь 26,9 \% опрошенных молодых людей среди тех, кто имеет сексуальный опыт, используют презервативы на регулярной основе, еще $27,2 \%$ стараются использовать презервативы во время секса, но у них это получается не всегда. 23,3 \% респондентов сообщили, что они используют презервативы крайне редко, 22,7 \% сообщили, что вообще не используют презервативы. Существуют четкие возрастные особенности использования презервативов: чем старше человек, тем выше вероятность того, что он не использует презервативы или использует крайне редко. Наиболее редко используют презервативы молодые люди, состоящие в браке. Кроме того, наиболее высок процент тех, кто не использует презервативы, в городе Ижевске.

Одновременно с этим за последние три года 47,4 \% респондентов проверялись на наличие заболеваний, передающихся преимущественно половым путем (ЗПППП), ежегодно или чаще, 29,9 \% проверялись один раз, а 22,7 \% не проверялись за указанный период. Мужчины проверяются на ЗПППП реже девушек - 63,2 \% против 87,6 \%. Старшие возрастные когорты проверяются реже (как правило, из-за наличия постоянного партнера), но и реже используют презерватив во время секса. Самый высокий процент тех, кто не проверяется на заболевания, передающиеся преимущественно половым путем, - среди жителей сельской местности.

Соответственно, в ходе опроса 17,8 \% респондентов сообщили, что у них регистрировались ЗПППП, еще 6,2 \% затруднились с ответом на этот вопрос. Среди жителей малых городов Удмуртии процент респондентов, сообщивших о выявленных ЗПППП, незначительно выше. Девушки чаще сообщают о заболеваниях, чем молодые люди (23,5 \% против 9,9\%). С возрастом вероятность встретить ответ о наличии ЗПППП возрастает.

Ситуация с озабоченностью репродуктивным здоровьем резко контрастирует с общей обеспокоенностью за состояние своего здоровья среди молодых людей [7. С. 269]. В целом 24 \% опрошен- 
ных считают себя полностью здоровыми, 53,4 \% скорее считают себя здоровыми, но констатируют, что периодически болеют, еще чуть менее 20 \% сообщили, что они не считают себя здоровыми людьми. Доминирующими причинами, которые способствуют появлению проблем со здоровьем, по мнению молодых людей, являются: стресс и волнения (70,6 \% опрошенных), «недосыпание» $(62,6$ \%), неполноценное питание $(61,4 \%)$, отсутствие занятий спортом (60,6 \%), плохая экология $(56,2 \%)$. Кроме того, $47,7 \%$ молодых людей сообщили, что они употребляют пиво, 29,4 \% употребляют «энергетики», 27,2 \% курят, 26,6 \% пьют алкогольные коктейли. Парни в два раза чаще девушек среди причин ухудшения здоровья выбирают вариант «я курю». С возрастом молодежь испытывает большие нагрузки на работе, недостаток времени и денег на лечение, запускает болезни. Жители Ижевска чаще других жалуются на плохую экологию и стрессы. С взрослением респондентов потребность в употреблении пива возрастает, в то время как потребность в коктейлях и «энергетиках» снижается.

\section{Заключение}

В результате проведенного исследования можно зафиксировать, что сегодня в Удмуртии складывается неблагоприятная демографическая ситуация, что связано как с особенностями половозрастной структуры населения, продолжающимся вторым демографическим переходом на территории Удмуртии (о его завершении можно говорить только в г. Ижевске), так и с уровнем смертности и убылью населения, которые резко выросли в пандемию COVID-19. Предварительные данные не дают оснований полагать, что демографическая ситуация изменится в лучшую сторону.

В настоящее время наблюдается минимальное число молодых людей, проживающих на территории Удмуртии, что связано с волновой структурой населения региона. Отчасти с этим же связаны ухудшения в основных демографических показателях, так как в настоящее время в репродуктивный и брачный возраст вступают малочисленные поколения 90-х гг.

В целом демографическая ситуация сглаживается продолжающимся в сельской местности Удмуртии демографическим переходом с сохраняющейся тенденцией к трехдетной модели семьи среди молодых людей. Кроме того, показатели рождаемости поддерживаются поколениями 80-х гг. рождения, которые реализуют двух-, трехдетную модель семьи.

Молодежь Удмуртии в целом ориентирована на романтические отношения, которые при относительной устойчивости должны перерастать в официально заключенные браки. Одновременно с этим косвенные оценки возраста вступления в брак, а также показателей разводов свидетельствуют о неустойчивости браков, их раннем возрасте заключения как для молодых женщин, так и для молодых мужчин. Соответственно, можно говорить о неподготовленности молодых людей к семейнобрачным отношениям при общей ориентации на них.

Вызывают тревогу показатели распространения ЗППП и использования контрацепции в более возрастных группах и семейных парах. С учетом общей неустойчивости браков, а также высокого уровня генерализации ВИЧ-инфекции (с уверенным ростом передачи половым путем) можно констатировать наличие высокого риска здоровья среди молодых людей.

\section{СПИСОК ЛИТЕРАТУРЫ}

1. Андрианова Е.В., Тарасова А.Н., Печеркина И.Ф. Мотивы и трудовые ценности молодежи: парадоксы развития // Мониторинг общественного мнения. Май-июнь 2018 г. № 3 (145). С. 306-323.

2. Ариф Э.М. Потребление в среде молодых активистов // Мониторинг общественного мнения. 2019. № 1 (149). Январь-февраль. С. 66-83.

3. Вишневский А.Г. Демографическая история и демографическая теория: курс лекций. М.: Изд. дом Высшей школы экономики, 2019. 368 с.

4. Калабихина И. Демографическая волна рождений и будущие колебания численности населения в разных возрастных группах: вызовы для социальной политики // Экономические стратегии. 2015. № 2. С. 49-56.

5. Кульпин С.В., Савчук Г.А., Якимова О.А. Зачем молодежь создает контент о здоровом образе жизни: факторный анализ тематических блогов // Мониторинг общественного мнения: экономические и социальные перемены. 2020. № 2. С. 168-190. https://doi.org/10.14515/monitoring.2020.2.656.

6. Литвина Д.А. Что значит быть настоящим: молодежные культуры в поисках аутентичности // Мониторинг общественного мнения. 2019. № 1 (149). Январь-февраль. С. 324-341.

7. Обухов К.Н. Волонтерское движение в Удмуртии: опыт социологического описания // Вестн. Удм. Ун-та. Социология. Политология. Международные отношения. 2020. Т. 4, вып. 3. С. 265-273. 
Семейные и репродуктивные установки молодых людей в Удмуртской Республике...

8. Обухов К.Н., Колесников Д.О. Социально-экономическое положение молодежи на территории Удмуртской Республики (по материалам ежегодного мониторинга «Молодежь Удмуртии») // Вестн. Удм. ун-та. Социология. Политология. Международные отношения. 2019. Т. 3, вып. 2. С. 131-138.

9. Одегов Ю.Г., Бабынина Л.С. Неустойчивая занятость как возможный фактор использования трудового потенциала молодежи России // Мониторинг общественного мнения. 2018. № 4 (146). Июль-август. С. 386-409.

10. Осипова И. Репродуктивные установки россиян и отношение к государственным мерам поддержки рождаемости // Демографическое обозрение. 2020. Т. 7, № 2. С. 97-120.

11. Радаев В.В. Миллениалы: Как меняется российское общество. 2-е изд. М.: Издательский дом НИУ ВШЭ, 2020. C. 120.

12. Рыбаковский О.Л., Таюнова О.А. Рождаемость населения России и демографические волны // Народонаселение. 2017. № 4. С. 56-66.

13. Статистика «Население». URL: https://udmstat.gks.ru/folder/51924 (дата обращения: 15.08.2021).

Поступила в редакцию 13.08.2021

Обухов Константин Николаевич, кандидат философских наук, доцент кафедры социологии

ФГБОУ ВО «Удмуртский государственный университет»

426034, Россия, г. Ижевск, ул. Университетская, 1 (корп. 6)

E-mail: fagotfrosch@gmail.com

\section{K.N. Obukhov \\ ATTITUDES TOWARDS FAMILY AND REPRODUCTION AMONG YOUNG PEOPLE IN THE UDMURT REPUBLIC (BASED ON THE DATA FROM "YOUTH OF UDMURTIA - 2019" MONITORING PROJECT)}

DOI: $10.35634 / 2587-9030-2021-5-3-311-321$

The article describes the key attitudes towards family and reproduction of young people living in the Udmurt Republic. The analysis used data obtained from an online survey of young people in the period from April 1 to August 31, 2019 $(\mathrm{n}=600)$ supplemented by up-to-date statistics of the local office of the Federal State Statistics Service for the Udmurt Republic for 2019 and 2020. Based on these materials, it is concluded that young people generally tend to look for a sexual partner and create a family, the sexual debut age stabilizes at the level of 17 years for men and 18 years for women, general health concerns increase among young people although sexual behavior prevails at a sufficiently high level of risk. Generally, based on the survey materials, we can confirm the desire of young people to have an average of 2 children with a slight bias towards the one-child family model. There are basic differences in attitudes towards family and reproduction among residents of cities and rural areas of Udmurtia. On the basis of statistics, it is concluded that currently in Udmurtia, the "wave nature" of the sex-age structure of the population remains, as well as a tendency to maintain concurrent high rates of marriage and divorce, which indicates that young people are unprepared for marriage but at the same time they acknowledge its value.

Keywords: youth, family, health, sexual behavior, STDs, contraception, marriage, divorce, fertility, Udmurtia.

\section{For citation:}

Obukhov K.N. Attitudes towards family and reproduction among young people in the Udmurt Republic (based on the data from "Youth of Udmurtia - 2019" monitoring project) // Bulletin of Udmurt University. Sociology. Political Science. International Relations. 2021. Vol. 5, iss. 3. P. 311-321. https://doi.org/10.35634/2587-9030-2021-5-3-311-321 (In Russ.).

Obukhov K.N., Candidate of Philosophy, Associate Professor at Department of Sociology

Udmurt State University

Universitetskaya st., 1/6, Izhevsk, Russia, 426034

E-mail: fagotfrosch@gmail.com 